\title{
Effects of the presence of annual killifish on the assemblage structure of resting stages of aquatic invertebrates in temporary ponds
}

\author{
Daiane Vendramin ${ }^{1}$, Camila Spaniol Klagenberg1, Marina Ramos Provensi ${ }^{1}$, Cristina Stenert ${ }^{1, *}$, \\ Mateus Marques Pires ${ }^{1}$, Elvio Sergio Figueredo Medeiros ${ }^{2}$, Martin Reichard ${ }^{3}$ and Leonardo \\ Maltchik $^{1}$
}

${ }^{1}$ Laboratory of Ecology and Conservation of Aquatic Ecosystems, UNISINOS University, Unisinos 950, São Leopoldo (RS), Brazil.

2 Semi-arid Rivers Ecology Group, State University of Paraíba, João Pessoa (PB), Brazil, Horácio Trajano de Oliveira, João Pessoa (PB), Brazil.

3 Academy of Sciences of the Czech Republic, Institute of Vertebrate Biology, Květná 8, 603 65, Brno, Czech

Republic.

* Corresponding author: cstenert@unisinos.br

Received: 05/09/18 Accepted: 14/02/19

\begin{abstract}
Effects of the presence of annual killifish on the assemblage structure of resting stages of aquatic invertebrates in temporary ponds

Predation pressure from vertebrates can affect the production of aquatic invertebrate resting stages in ponds, but the effects of seasonal predation on the assemblages of their hatchlings remains poorly understood. This study assessed the effects of the presence and density of annual killifish predators on the structure of assemblages of aquatic invertebrate hatchlings, as well as on the density and size of cladoceran eggs in southern Brazil temporary ponds. Dry sediment samples were collected from ponds that differed according to the presence and density of annual fishes, being four ponds without annual fish and four with annual fish at various densities. We detected no difference in density and size of cladoceran eggs between ponds with and without annual fish. Model selection procedures showed that the hatchling assemblage structure (richness, abundance and composition) did not change in relation with fish presence. Nonetheless, richness and abundance of hatchlings was lower in ponds with higher densities of annual fish. Our results suggest a limited effect of annual fish predators on the assemblage structure of resting stages of aquatic invertebrates, which can be related to dietary, ontogenetic and stochastic contingencies associated with populations of annual fish. In particular, the effect of annual fish on aquatic invertebrate hatchlings seemed to be more related with predator density.
\end{abstract}

Key words: dormancy, ephippial egg, body size, annual fish, intermittent wetlands

\section{RESUMO}

Efeitos da presença de peixes anuais sobre a estrutura da comunidade dormente de invertebrados aquáticos em áreas úmidas temporárias

A pressão de predação de vertebrados pode influenciar a produção de estágios dormentes de invertebrados aquáticos em áreas úmidas, embora os efeitos de predadores com ciclos de vida sazonais sobre a estrutura de comunidades dormentes seguem pouco compreendidos. Este estudo avaliou os efeitos da presença e densidade de espécies predadoras de peixes anuais sobre a estrutura da comunidade dormente de invertebrados aquáticos, bem como sobre a densidade e tamanho dos ovos efipiais de cladóceros em áreas úmidas temporárias do extremo sul do Brasil. Amostras de sedimentos secos foram coletadas em áreas úmidas que diferiram de acordo com a presença e densidade de espécies de peixes anuais, sendo quatro áreas úmidas sem peixes anuais e quatro com peixes anuais, em diferentes densidades. Não foram encontradas diferenças na densidade e no tamanho dos ovos efipiais de cladóceros entre as áreas úmidas com e sem peixes anuais. 
Resultados das análises estatísticas mostraram que a riqueza, a abundância e a composição dos invertebrados aquáticos emergentes de estágios dormentes não variaram em função da presença de peixes. Por outro lado, análises restritas às áreas úmidas com peixes anuais indicaram menor riqueza e abundância de invertebrados aquáticos emergentes de estágios dormentes associados às áreas úmidas com maiores densidades de peixes anuais. Nossos resultados sugerem um efeito limitado de peixes anuais predadores sobre a estrutura da comunidade dormente de invertebrados aquáticos. Esses resultados podem estar relacionados à dieta, ontogenia e à estocasticidade das populações de peixes anuais. De fato, o efeito de peixes anuais sobre os invertebrados aquáticos emergentes de estágios dormentes parece estar mais relacionado à densidade de predadores.

Palavras chave: dormência, efípios, tamanho corporal, peixes anuais, áreas úmidas intermitentes

\section{INTRODUCTION}

The sediment of intermittent wetlands harbors resting stages of several species of aquatic invertebrates, which are able to resist to periods of hydric stress (Brendonck \& De Meester, 2003; Gaikwad et al., 2008). The production of resting stages by aquatic invertebrates is an important strategy in response to a range of physical, chemical and biological stimuli such as lack of water, extreme temperatures, low levels of dissolved oxygen, as well as variations in photoperiod, competition and predation (Williams, 1993; Brendonck \& De Meester, 2003; Williams, 2006; Sipaúba-Tavares et al., 2014). Within these communities, aquatic invertebrates (mostly zooplanktonic microcrustaceans) present low active dispersal abilities, thus resting stages enable long-term maintenance of a diverse range of species and genotypes, as well as their coexistence with competitors and predators (Santangelo, 2009). The production of these resting stages is also usually associated with the allocation of resources for the production and subsequent growth of the hatchlings (Santangelo et al., 2011).

The accumulation of these resting stages over time and fluctuations in environmental conditions interact to affect patterns of richness, abundance and biomass of aquatic invertebrate assemblages (Vandekerkhove et al., 2005). Changes in zooplankton assemblage structure, for instance, can potentially impact the dynamics and the energy flow of aquatic food webs (Sakwińska, 2002; Fahd et al., 2007; Santangelo et al., 2010; Hammill et al., 2015). This is because zooplankton resting stages are important for the recruitment of food sources for higher trophic-level predators such as fish, which prey mostly on adult stages of the zooplankton (Jenkins \& Boulton, 2007).

A range of factors is known to affect the production of resting stages by aquatic invertebrates. In particular, predation pressure from vertebrates like fish represents an important factor stimulating the production of resting stages of zooplankton species (Nielsen et al., 2000; Ślusarczyk, 1995, 1999, 2001; Dzialowski et al., 2003; Jenkins \& Boulton, 2007; Santangelo et al., $2010,2011)$. The egg production by many zooplankton species, as well as the stimulation of other defense mechanisms (Nielsen et al., 2000; Santangelo et al., 2010, 2011; Tollrian et al., 2015), can increase in the presence of fish, especially as an anti-predatory response (Ślusarczyk, 1995, 1999, 2001; Dzialowski et al., 2003; Mikulski \& Pijanowska, 2009). In fact, predation by fish is known to affect the diversity of aquatic communities (Walseng et al., 2015). It has been reported to lead to a reduction in the abundance of larger-bodied zooplankton species (Jeppesen et al., 2002; Iglesias et al., 2008, 2011), and in the density of resting stages in the sediment (Nielsen et al., 2000; Ślusarczyk, 2001).

In temporary ponds, predation pressure is generally assumed to increase with the reduction of the flooding area throughout the drying season (Medeiros \& Arthington, 2008; Silva et al., 2010). In addition, not only the presence of predators affects the structure of prey assemblages, but it has been shown that the effects of predation are density-dependent, and should become more significant with increasing levels of predator density (Nilsson, 2001). Furthermore, studies describe changes in the defense strategies and composition of zooplankton prey according to different levels of predator densities (Iglesias et al., 2011; Tollrian et al., 2015). 
However, much of the literature on the effects of fish predation on zooplankton is concerned with non-annual fish species, i.e., species without seasonal life cycles (Pijanowska \& Stolpe, 1996; Jeppesen et al., 2001; Mergeay et al., 2006; Meerhoff et al., 2007; Mazzeo et al., 2010; Zhang et al., 2013). In the Neotropical region, small and omnivorous fish species are common and abundant (Iglesias et al., 2011), but some of these species have annual life cycles, also being capable of producing resting eggs (Keppeler et al., 2013, 2015; Lanés et al., 2013, 2015). The food items of these fish comprise mostly of aquatic invertebrates that produce resting stages (Laufer et al., 2009; Keppeler et $a l ., 2013,2015)$. Hence, the population dynamics of these predators should have an important influence on the assemblage structure of invertebrate resting stages.

In this study, we assessed the effects of predatory annual fish species on the assemblage structure of the hatchlings of aquatic invertebrates, and on the density and morphology of the resting eggs of cladocerans, in temporary ponds of southern Brazil. To achieve that, incubation experiments were conducted to obtain the emergence of resting stages of aquatic invertebrates, and flotation performed for the retrieval of zooplankton (Cladocera) eggs. We initially evaluated the effect of the presence of annual fish on aquatic invertebrate assemblages by comparing ponds where predatory annual fish were either present or absent. Secondly, we assessed the effects of different fish densities (or population sizes) on aquatic invertebrate assemblages, by restricting the analyses to ponds where annual fish occurred. Based on the assumptions that an increase in the production of resting stages is expected in the presence of predators (Nielsen et al., 2000; Ślusarczyk, 2001; Santangelo et al., 2010, 2011) and that predation by fish has been reported to influence the body size of the hatchlings (Iglesias et al., 2011), we developed the following expectations: (i) richness and abundance of the hatchlings of aquatic invertebrates will be lower in ponds with higher densities of predators; and (ii) cladoceran eggs will have higher density and smaller size in ponds with higher densities of annual fish.

\section{MATERIAL AND METHODS}

\section{Study area and site characterization}

The study area is located near the Ramsar site Lagoa do Peixe National Park ( $31^{\circ} 00^{\prime} 46^{\prime \prime}$ to $31^{\circ}$ 29' $00^{\prime \prime} \mathrm{S}$ and $50^{\circ} 46^{\prime} 31^{\prime \prime}$ to $\left.51^{\circ} 09^{\prime} 51^{\prime \prime} \mathrm{W}\right)$, in the Coastal Plain of Rio Grande do Sul, southern Brazil (Maltchik et al., 2003). The climate in the study area is humid temperate, without a dry season and with a hot summer (Peel et al., 2007). The average annual temperature is $\sim 17.5^{\circ} \mathrm{C}$, ranging from $13{ }^{\circ} \mathrm{C}$ in winter to $24^{\circ} \mathrm{C}$ in summer, and the annual average precipitation ranges from 1200 to $1500 \mathrm{~mm}$. The topography is characterized by flat lowland terrain, with altitudes lower than $20 \mathrm{~m}$ above sea level (Rambo, 2000).

Eight temporary ponds located in the surroundings of the Lagoa do Peixe National Park were selected for study. Four of these ponds contained populations of two species of annual killifish: Austrolebias minuano Costa and Cheffe 2001 and Cynopoecilus fulgens Costa, 2002. Previous studies showed that both species feed on microcrustaceans and other small invertebrates (Keppeler et al., 2013, 2015; Lanés et al., 2016). In addition, small individuals (approx. $3.0 \mathrm{~cm}$ ) of nine non-annual fish species from five families co-existed with the annual fish: Poeciliidae (Phalloceros caudimaculatus (Hensel, 1868)); Callichthydae (Corydoras paleatus (Jenyns, 1842)); Characidae (Astyanax cf. eigenmanniorum (Cope, 1894), Hyphessobrycon boulengeri (Eigenmann, 1907), Hyphessobrycon aff. igneus Miquelarena, Menni, López \& Casciotta 1980, Mimagoniates inequalis (Eigenmann, 1911) and Cheirodon interruptus (Jenyns, 1842)); Erythrinidae (Hoplias aff. malabaricus (Bloch, 1794)); and Curimatidae (Cyphocharax voga (Hensel, 1870)).

Sampling conducted by Lanés et al. (2016) during the same hydrologic year of the present study did not detect the occurrence of neither annual killifish nor non-annual species in the other four ponds selected. The absence of annual killifish species is a known feature in some temporary ponds of the southern Brazil Coastal Plain (Lanés et al., 2018). This is likely the result of a patchy distribution and limited dispersal ability of annual fish (Reichard, 2015). The 
absence of fish predators other than annual killifish has also been noticed in several of those temporary ponds (Lanés et al., 2018).

In ponds containing fish, the seasonal dynamics of the populations of both annual killifish and the other non-annual fish species has been studied during the hydrologic year of 2014 (Lanés et al., 2016). Both killifish species had similar seasonal dynamics, although their population sizes (as well as those of the non-annual species) varied among ponds (A. minuano: from 1 to 1700 individuals; $C$. fulgens: from 1 to 1600 individuals). Additional information on the seasonal dynamics and composition of non-annual fish has been published by Lanés et al. (2016).

Environmental information on some of the sampled ponds are provided in Rolon et al. (2011) and Lanés et al. (2016). The sampled ponds had no physical connection with each other. They were separated by distances of up to $0.7 \mathrm{~km}$, but were occasionally connected with other permanent aquatic systems during flooding periods (Lanés et al. (2016). The study ponds had similar superficial areas (approximately $0.5 \mathrm{ha}$ ), and their waters were well oxygenated (average dissolved oxygen concentration of $10.3 \pm 0.8 \mathrm{mg} / \mathrm{L})$, neutral to slightly alkaline (average $\mathrm{pH}$ of $6.6 \pm 0.2$ ), and with average electrical conductivity of $10.0 \pm 4.1$ $\mathrm{mS} / \mathrm{cm}$. The hydroperiod length was similar across ponds, with surface water being present between March-April and November-December (Stenert et al., 2012; Lanés et al., 2016). The aquatic macrophyte assemblages were comprised of submerged and emergent species, mostly Micranthemum sp. and species of Poaceae, Cyperaceae and Juncaceae. Predatory macroinvertebrates (Ceratopogonidae, Dytiscidae, Belostomatidae, Pleidae, Libellulidae, Hirudinea and water mites) were observed in all ponds, regardless of the presence of annual killifish (Stenert et al., 2012; Keppeler et al., 2013).

\section{Sediment sampling and experimental methods}

Sediment samples were collected on April 2015 (in the subsequent hydrologic year following the study of the seasonal dynamics of fish populations), when the ponds were dry. This procedure should allow the assessment of any effect of the variation in annual fish populations over the previous hydrologic year on the egg bank present in the sediment. Fifteen randomly distributed subsamples were taken from each pond with a core sampler $(7.5 \mathrm{~cm}$ diameter $)$ inserted $5 \mathrm{~cm}$ deep into the sediment (Brendonck \& De Meester, 2003). These subsamples were subsequently pooled to represent the entire pond and stored in black plastic bags $(20 \mathrm{~L})$ and kept refrigerated $\left(4-8{ }^{\circ} \mathrm{C}\right)$ for further analysis (Maia-Barbosa et al., 2003). At the laboratory, the sediment was sieved ( $1 \mathrm{~mm}$ sieve) for the removal of leaves and roots and posteriorly homogenized. Two batches of sediment were taken to test each of the proposed predictions.

The sugar flotation method (modified from Vandekerkhove et al. (2004a) and Iglesias et al. (2016)) was used to evaluate the density and size of cladoceran resting eggs between ponds with and without annual fish predators. This method was employed for the $600 \mathrm{~g}$ samples representing each pond, where the sediment was added to a $1: 1$ mix of distilled water and table sugar. Fifteen $\mathrm{mL}$ of this solution was centrifuged at $3000 \mathrm{rpm}$ for 3 minutes and the supernatant was washed through a $53 \mu \mathrm{m}$ mesh using distilled water. The resting eggs of cladocerans were then separated by morphotypes, counted and measured for their length on a petri dish under a stereomicroscope. Density was expressed as the number of eggs per $\mathrm{cm}^{3}$. A total of 206 eggs (107 eggs in ponds with annual fish and 99 eggs in ponds without annual fish) had their length measured (mm) using an ocular micrometer. Since there is a strong correlation between the size of the ephippium egg and the size of the hatched cladoceran (Jeppesen et al., 2002; Vandekerkhove et al., 2004b), the egg size was taken as a proxy for the hatched cladoceran size.

The incubation experiment was carried out using $1000 \mathrm{~g}$ of dry sediment distributed into two plastic trays $(30.3 \mathrm{~cm}$ in length, $22.1 \mathrm{~cm}$ wide and $7.5 \mathrm{~cm}$ deep) for each pond (500 g per tray), totaling 16 trays for the experiment. The sediment of each tray was submerged under $2 \mathrm{~cm}$ of reconstituted water (distilled water formulated for the cultivation of zooplanktonic species): $\mathrm{pH}$ between 7.0 and 7.6 and hardness between 40 
and $48 \mathrm{mg} / \mathrm{L}$ of $\mathrm{CaCO}_{3}$ (according to the guidelines proposed by ABNT NBR 13373, 2006). Water level, temperature $\left(23 \pm 2{ }^{\circ} \mathrm{C}\right)$, photoperiod (12 hours light/dark cycle) and dissolved oxygen were monitored and kept constant over the incubation period (see Stenert et al., 2010; Ávila et al., 2015). The incubation period was 35 days (five weeks), and the collection of hatched organisms was conducted 15 times (following intervals of 2-3 days between each collection) within this period to avoid reproduction. Other studies used similar sampling intervals to ensure that the microfauna collected was from the egg bank and not from reproduction (Nielsen et al., 2003; Brock et al., 2005, Nielsen et al., 2013). Hatchlings were collected with a $53 \mu \mathrm{m}$ net with the same width as the trays by agitating the sediment and then sweeping three times on the surface water. The contents of the three sweeps were transferred to a petri dish and observed under the stereomicroscope. Any unhatched eggs or resting stages were returned to the trays. Hatched organisms were stored in $80 \%$ ethanol and identified to the level of species (Lopretto \&

Table 1. Composition, richness and abundance of hatched invertebrates in ponds with and without annual fish. Composição, riqueza e abundância de invertebrados emergentes em áreas úmidas com e sem peixes anuais.

\begin{tabular}{|c|c|c|c|c|c|c|c|c|c|}
\hline \multirow[t]{2}{*}{ Taxa } & \multicolumn{4}{|c|}{ Ponds with annual fish } & \multicolumn{4}{|c|}{ Ponds without annual fish } & \multirow[t]{2}{*}{ Abundance } \\
\hline & $\mathrm{P} 1$ & $\mathrm{P} 2$ & P3 & $\mathrm{P} 4$ & $\mathrm{P} 1$ & $\mathrm{P} 2$ & P3 & $\mathrm{P} 4$ & \\
\hline \multicolumn{10}{|l|}{ Cladocera } \\
\hline Camptocercus simili & 4 & 8 & 0 & 0 & 14 & 0 & 0 & 3 & 29 \\
\hline Ceriodaphnia silvestrii & 1 & 1 & 0 & 0 & 3 & 0 & 0 & 0 & 5 \\
\hline Chydorus eurynotus & 14 & 37 & 15 & 0 & 20 & 12 & 7 & 100 & 205 \\
\hline Leberis davidi & 18 & 15 & 4 & 14 & 27 & 6 & 14 & 51 & 149 \\
\hline Leydigia striata & 39 & 0 & 7 & 13 & 11 & 1 & 13 & 2 & 86 \\
\hline Macrothrix elegans & 53 & 38 & 5 & 0 & 7 & 2 & 2 & 24 & 131 \\
\hline Macrothrix laticornis & 41 & 21 & 2 & 0 & 2 & 1 & 2 & 29 & 98 \\
\hline Magnospina dentifera & 7 & 3 & 0 & 0 & 1 & 0 & 1 & 16 & 28 \\
\hline \multicolumn{10}{|l|}{ Ostracoda } \\
\hline Cypretta vivacis & 250 & 20 & 2 & 1 & 114 & 8 & 2 & 12 & 409 \\
\hline Chlamydotheca riograndensis & 17 & 2 & 0 & 2 & 6 & 2 & 0 & 0 & 29 \\
\hline Cyprididae & 1 & 1 & 0 & 0 & 12 & 0 & 0 & 0 & 14 \\
\hline Copepoda & 6 & 6 & 50 & 3 & 1 & 1 & 1 & 8 & 76 \\
\hline Anostraca & 1 & 0 & 0 & 0 & 1 & 2 & 0 & 0 & 4 \\
\hline Rotifera & 1 & 0 & 0 & 0 & 0 & 0 & 0 & 4 & 5 \\
\hline Collembola & 1 & 4 & 0 & 2 & 0 & 0 & 1 & 3 & 11 \\
\hline \multicolumn{10}{|l|}{ Platyhelminthes } \\
\hline Mesostoma ehrenbergii & 5 & 1 & 0 & 0 & 1 & 0 & 1 & 0 & 8 \\
\hline Gieysztoria sp. 1 & 0 & 1 & 2 & 4 & 0 & 0 & 0 & 1 & 8 \\
\hline Gieysztoria sp. 2 & 0 & 0 & 1 & 0 & 0 & 0 & 0 & 0 & 1 \\
\hline Nematoda & 0 & 1 & 0 & 1 & 0 & 0 & 0 & 1 & 3 \\
\hline Richness & 16 & 15 & 9 & 8 & 14 & 9 & 10 & 13 & 19 \\
\hline Abundance & 459 & 159 & 88 & 40 & 220 & 35 & 44 & 254 & 1299 \\
\hline
\end{tabular}


Tell, 1995; Elmoor-Loureiro, 1997; Gazulha, 2012). Voucher specimens are stored in the collection of the Laboratory of Ecology and Conservation of Aquatic Ecosystems of UNISINOS.

\section{Data analysis}

We compared the richness and abundance of hatched organisms between temporary ponds with and without annual fish species using generalized linear mixed-effects models (GLMM). In this step, fish presence (levels: present; absent) was considered the fixed factor and the days of collection during the experiment $(\mathrm{N}=15)$ the random factor. This accounted for the repeated-measurements design of the experiment and resultant non-independence of the data. Model parameters were estimated by maximum likelihood (Laplace approximation), and the statistical significance was assessed through comparison with null models (random intercept and random factor). In addition, we controlled for possible effects of null values in the response dataset of model fitting by comparing the performance of zero-inflated and non-zero inflated models (i.e., we fitted models with the option 'zero inflation' activated and deactivated). Finally, residual values were assessed to check the model assumptions.
Subsequently, we used GLMMs to test for possible effects of different densities of the annual fish species in each temporary pond on the richness and abundance of hatched organisms, where we constrained the analysis to ponds with annual fish present. In this step we took into account the repeated-measurement design of the study (i.e., the re-sampling events of the experiment) by including it as the random factor in the analysis. The standard procedures used in the analysis of the effect of fish presence were repeated with the assessment of the performance of zero-inflated models followed by testing of model significance through comparison with null models. Models were also fitted with negative binomial distribution and subject to assessment of their diagnostic plots. The fixed factor considered in this case was pond identity, which corresponded to sites with different fish densities. We also fitted models with the densities of each annual fish species as predictors (i.e., models with continuous predictors). In the continuous models, we assessed the effects of isolated, additive and interaction effects of the density of each annual fish. These procedures, however, yielded results similar to the categorical models, and we report the patterns derived only from the latter.

In both steps, all models were fitted with negative binomial and Poisson error distributions

Table 2. Log-scale results of the best-fit models $(\triangle \mathrm{AICc}<2)$ for the effects of presence and density (or population size) of annual fish species on hatchling invertebrate assemblages ( $\mathrm{df}=$ degrees of freedom; $* * *=$ zero-inflated models; values in parentheses indicate standard errors). Resultados (escala log) dos modelos com melhor ajuste ( $\triangle A I C c<2)$ para os efeitos da presença e densidade (tamanhos populacionais) de peixes anuais sobre as comunidades de invertebrados aquáticos (df $=$ graus de liberdade; $* * *=$ modelos com inflação de zero; valores entre parênteses referem-se a erros-padrão).

\begin{tabular}{|c|c|c|c|c|c|c|c|c|c|}
\hline Predictor & Outcome & Best model & Intercept & & Fixed facto & & $\triangle \mathrm{AICc}$ & df & $\begin{array}{l}\text { Akaike } \\
\text { weights }\end{array}$ \\
\hline \multirow{5}{*}{$\begin{array}{l}\text { Annual fish } \\
\text { presence }\end{array}$} & & & \multicolumn{7}{|c|}{ Fish (present) } \\
\hline & Richness & $\sim 1+(1 \mid$ days $)$ & 0.92 & & & & 0 & 3 & 0.71 \\
\hline & & $\sim$ Annual fish presence $+(1 \mid$ days $)$ & 0.88 & & 0.96 & & 1.8 & 4 & 0.28 \\
\hline & Abundance & $\sim 1+(1 \mid$ days $)$ & 2.15 & & & & 0 & 3 & 0.39 \\
\hline & & $\sim$ Annual fish presence $+(1 \mid$ days $)$ & 1.99 & & 2.32 & & 0.18 & 4 & 0.35 \\
\hline \multirow{4}{*}{$\begin{array}{l}\text { Annual fish } \\
\text { population } \\
\text { size (density) }\end{array}$} & & & Fixed factor & & & & & & \\
\hline & & & $\begin{array}{c}\text { Pond } 1 \\
\text { (Intercept) }\end{array}$ & Pond 2 & Pond 3 & Pond 4 & & & \\
\hline & Richness & $\sim$ Pond $+(1 \mid \text { days })^{* * *}$ & $1.46(0.17)$ & $1.15(0.18)$ & $0.46(0.22)$ & $0.53(0.22)$ & 0 & 6 & 0.39 \\
\hline & Abundance & $\sim$ Pond $+(1 \mid \text { days })^{* * *}$ & $3.29(0.3)$ & $2.41(0.33)$ & $1.35(0.35)$ & $0.99(0.36)$ & 0 & 7 & 0.28 \\
\hline
\end{tabular}


(due to the discrete nature of the response data), from which negative binomial-fitted ones yielded less overdispersion. Model selection procedures were based on the Akaike information criteria adjusted for small sample sizes (delta AICc) (Burnham \& Anderson, 2002), and were conducted with codes provided in Kedem et al. (2014). Only models with delta $\mathrm{AICc}<2$ were retained for further inference. We fitted all the GLMMs in the $\mathrm{R}$ statistical environment v. 3.4.2 using the function $\operatorname{glmm} A D M B$ of the package $\operatorname{glmm} A D M B$ v. 0.8.3.3 (Skaug et al., 2016).

The evaluation of dissimilarities in invertebrate composition across ponds was performed using Non-Metric Multidimensional Scaling (NMDS). This analysis was performed with a dissimilarity matrix (Bray-Curtis index) of the log-transformed abundance of the fauna. A non-parametric Multivariate ANOVA followed by 9999 permutations (PERMANOVA) was used to test for differences in taxa composition between ponds with and without annual fish, using the same dissimilarity matrix as in the ordination diagram. All statistical analyses were performed in the statistical environment of $\mathrm{R} \mathrm{v}$. 2.9.0 (R Development Core Team, 2009).

\section{RESULTS}

We collected 1299 individuals from 19 taxa that hatched from the incubation experiment. Cladocera was the most abundant group, with 731 individuals $(56.2 \%)$ from eight species: Chydorus eurynotus (15.7\%), Leberis davidi (11.4 \%), Macrothrix elegans (10.1\%), Macrothrix laticornis (7.5\%), and Leydigia striata (6.6 $\%)$ being the most abundant species. Ostracoda was also abundant, with 452 individuals (34.7\%) from three taxa: Cypretta vivacis (31.4 \%), Chlamydotheca riograndensis $(2.2 \%)$ and Cyprididae $(1.0 \%)$. Other invertebrates that emerged were Copepoda (5.8\%), flatworms (1.4\%), Collembola $(0.8 \%)$, Anostraca $(0.3 \%)$ and Nematoda $(0.2$ $\%)$. In ponds with annual fish, cladoceran species represented $45 \%$ of the hatched invertebrates, followed by Cypretta vivacis (273 hatched individuals, $36.6 \%$ ). Similar results were observed in ponds without annual fishes: Cladocera was the dominant group $(60.2 \%$ of the
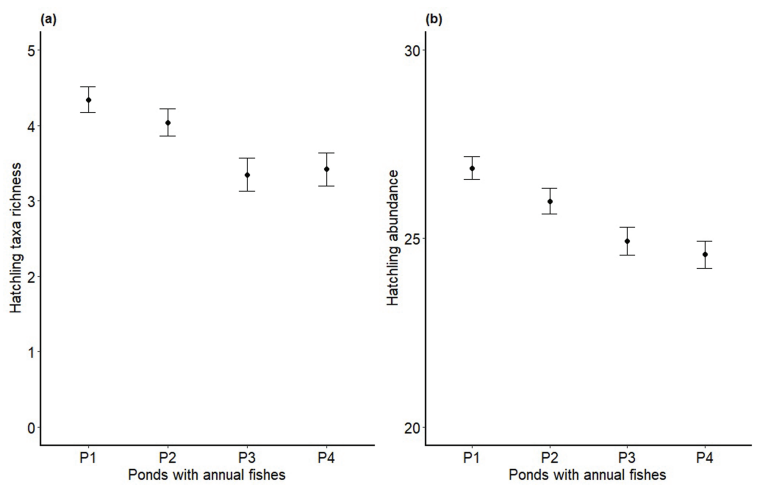

Figure 1. Richness (a) and abundance (b) of aquatic invertebrate hatchlings in ponds with annual fish (bars represent standard errors). Riqueza (a) e abundância (b) de invertebrados aquáticos emergentes de estágios dormentes em áreas úmidas com peixes anuais (barras de erro indicam erros-padrão da média).

hatched invertebrates), followed by Cypretta vivacis (136 individuals; $24.6 \%$ ) (Table 1).

With regard to the effects of annual fish species on the richness of aquatic invertebrate hatchlings, model selection procedures showed that the inclusion of the effects of the presence of annual fish was not effective to increase model fit in relation to null models. A similar pattern was detected for the abundance of invertebrates over the experiment, as models including the presence of annual fish as predictor did not contribute to explain the pattern of the number of hatched individuals (Table 2).

In contrast, in the analyses restricted to temporary ponds with annual fish, the best-fit models included pond identity as an important predictor to explain variation in richness and abundance of hatched invertebrates. In summary, the best-fit models showed that taxa richness and the number of hatched invertebrates were higher in the ponds containing the lower densities of both annual fish species. Models treating the independent variables as continuous also detected negative trends of annual fish densities on invertebrate assemblages (Table 2) (Fig. 1).

The NMDS ordination diagram $($ stress $=0.054)$ indicated a high degree of overlap in aquatic invertebrate composition between ponds with and without annual fish (Fig. 2), which was confirmed by PERMANOVA, as no effect of fish presence was 
detected on overall composition of emergent invertebrates ( $p$ seudo- $F=0.069, p=0.827$ ).

We collected 3139 eggs using the flotation method. Most eggs came from the ponds with annual fish $(72.7 \%)$. Egg density ranged between 0.2 and $1.7 \mathrm{eggs} / \mathrm{cm}^{3}$ (mean $=0.76 \mathrm{eggs} / \mathrm{cm}^{3}$; std. error $=0.07$ ). This trend was driven by two ponds containing annual fish, which harbored $61.4 \%$ of all the eggs. In the ponds without annual fish, the egg density was similarly low across ponds, ranging from 0.2 to $0.3 \mathrm{eggs} / \mathrm{cm}^{3}$ (mean $=0.31$ eggs $/ \mathrm{cm}^{3}$; std. error $=0.03$ ). In ponds with annual fish the minimum and maximum egg sizes were $0.2 \mathrm{~mm}$ and $1.1 \mathrm{~mm}$ (mean $=0.49 \mathrm{~mm}$; std. error $=$ $0.05)$. Similarly, in ponds without annual fish the minimum and maximum egg sizes were $0.2 \mathrm{~mm}$ and $1.1 \mathrm{~mm}($ mean $=0.47 \mathrm{~mm}$; std. error $=0.05)$.

\section{DISCUSSION}

On our first experiment we detected no effect of the presence of annual fish on the assemblage structure of aquatic invertebrate hatchlings, as the richness, abundance and composition of hatchlings did not vary between ponds with and without annual fish. This result contrasted with previous findings that reported an influence of fish predators on zooplankton assemblages. The exposure to fish by zooplankton has been associated with reductions in their abundance and richness, as well as changes in their assemblage composition, mostly due to the microcarnivorous feeding habits of many fish species (Zaret, 1980; Lemma et al., 2001; Zhang et al., 2013). In addition, zooplankton species are important items on the diet of annual fish occurring in southern Brazil subtropical ponds (Keppeler et al., 2013, 2015).

However, most studies were conducted with the adult and active stages of the zooplankton rather than their hatchlings. Santangelo (2009) and Iglesias et al. (2016), for instance, showed that the effects of fish predators on the hatchlings of cladoceran species are not straightforward, as the hatching of cladoceran species was not affected by fish cues during their study. This can be observed in studies on the assemblage composition of surface sediments that described the occurrence of species of Daphnia in African and Uruguayan lakes where several predatory fish

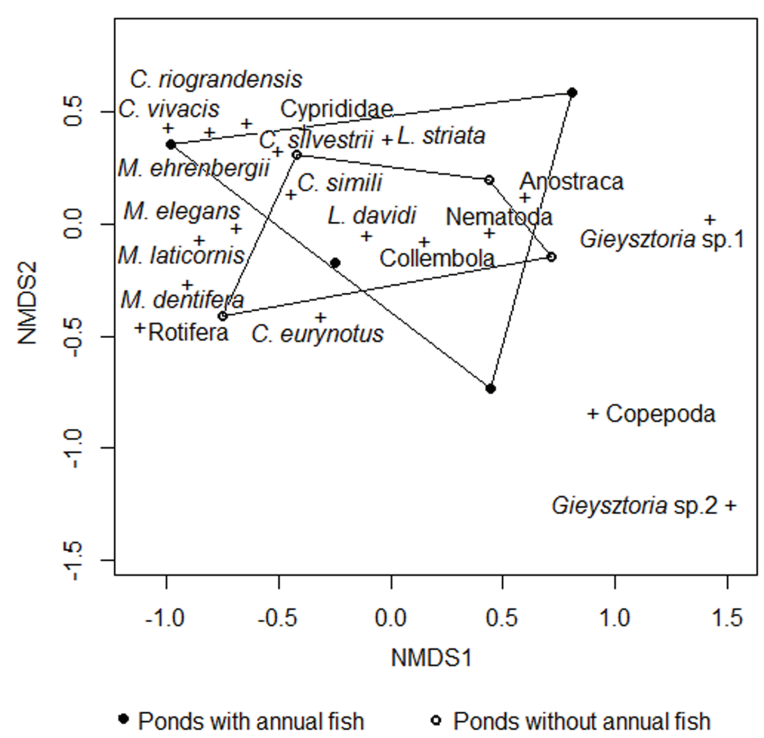

Figure 2. Non-metric multidimensional scaling (NMDS) diagram of the assemblage structure of aquatic invertebrate hatchlings after incubation of the sediment from ponds with and without annual fish. ('+' represents invertebrate species). Diagrama de ordenação multidimensional não-métrico da estrutura da comunidade de invertebrados aquáticos emergentes de estágios dormentes após a incubação do sedimento de áreas úmidas com e sem peixes anuais. ('+' indicam as espécies de invertebrados).

occur (Mergeay et al., 2006; Iglesias et al., 2011). In addition, species-level experiments by Bozelli et al. (2008) described no difference in the abundance of hatchlings of Daphnia obtusa in relation to fish presence, and data from Santangelo et al. (2010, 2011) showed that fish cues did not influence the hatching of Moina micrura and Diaphanosoma birgei.

In general, our results agree with the reviews of Santangelo (2009) and Iglesias et al. (2016), evidencing that fish presence does not necessarily affect the termination of diapause in zooplankton species and explaining the lack of effect on the assemblage structure of the hatchlings. In fact, the eggs of some zooplankton species need to undergo two or more exposures to adverse factors, such as fish cues, to hatch (De Meester \& De Jager, 1993). This non-synchronized hatching is referred to as a bet-hedging strategy (Slatkin, 1974). Since we conducted a single experiment and the population sizes of annual fish vary over 
time, these could be the explanations for the absence of effect of fish presence on richness and abundance of hatchlings.

It should be noticed that most of the studies that describe the effects of fish on zooplankton are conducted with non-annual species. Therefore, one possible explanation for the lack of effect of the presence of annual fish on emergent resting stages of invertebrates is the interannual variability in fish occurrence across ponds (Lanés et al., 2014). Populations of many species of annual fish inhabiting temporary ponds of southern Brazil generally show high stochasticity and fluctuations in their size across hydrologic years (Keppeler $e t$ al., 2013, 2015), including the two species present in the study ponds (Lanés et al., 2014). Given that invertebrate resting stages accumulate in the pond sediment over time (Williams, 2006), the long-term persistence of propagule bank could have masked any immediate impact associated with the presence of fish predators in the hydrologic year studied. If the presence of fish indeed varies among years, our study suggests an absence of short-term effects (one single annual life cycle) of the presence of fish predators on abundance, richness and composition of aquatic invertebrate hatchling assemblages.

Additionally, the lack of effect of annual fish presence on the egg density and size can be explained by ontogenetic contingencies associated with the life cycles of the annual fish. Studies have highlighted the importance of the body size of the predator as a factor when selecting their prey (Brooks \& Dodson, 1965). This is the case of the small-sized annual killifishes, which have been reported to predate on smaller body-sized zooplankton (Ortiz \& Arim, 2016). The maximum body size of the species of killifish occurring in the study area ranges from 15 to $40 \mathrm{~mm}$ (Gonçalves et al., 2011). Those species are commonly generalist feeders with important seasonal variation in diet composition (Keppeler et al., 2013). For instance, Arenzon et al. (1999) pointed out that despite the fast growth and early maturity of annual fish, individuals required at least two months to reach their maximum size and therefore broaden their diet and lay resting stages. This period is longer than the incubation period of the zooplankton in the sediment (Iglesias et al.,
2016, and data presented therein), which represents a faster reproductive cycle (under favorable conditions), thus avoiding intense predation. This is supported by other studies (Siziba et al., 2013) showing that the effect of fish predation on invertebrates in intermittent wetlands is stronger in areas where the hydroperiod is long enough for the fish to reach its full size and maturity. Furthermore, the resting stages of annual fish can respond to different environmental cues in comparison with zooplankton resting eggs, suggesting that the eggs from these annual fish do not necessarily have an emergence that is synchronized with that of the zooplankton, reducing predation pressure on the latter.

Our results seem to be in accordance with the findings from Brendonck \& De Meester (2003), who stated that the dynamics of the assemblages of resting stages is not related to immediate effects occurring in the previous hydrological season. The review of Iglesias et al. (2016) also leads to a similar direction, since fish predation seems to affect the structure of the active zooplankton and some behavioral responses in their species, but not the diapause. Therefore, this is an indicative that fish presence should have little effect on the assemblage structure of zooplankton resting stages, as detected by the lack of changes in the hatchling assemblage.

Our second evaluation, on the other hand, detected more pronounced differences in the hatchling assemblages within the group of temporary ponds containing annual fish, where temporary ponds containing higher densities of annual fish had lower richness and abundance of hatchlings. There were important differences in egg density among ponds with varying predator densities as opposed to fish presence. More specifically, two of the four ponds with annual fish had pronouncedly higher egg density, likely associated with the higher population sizes of annual fish.

Those results reinforce the idea that defense mechanisms such as the production of resting eggs are density-dependent (Tollrian et al., 2015), as found by other studies throughout the world (Iglesias et al., 2008, 2011; Mazzeo et al., 2010), and despite the reduced sample size of this study. Studies conducted with resting stages in a 
paleolimnological time frame in African natural lentic systems assessed long-term effects of changing levels of predation pressure on the zooplankton and these studies revealed negative effects of increasing fish densities on emerging species of Daphnia (Mergeay et al., 2004). Temporally more restricted studies have also found similar results with higher mean egg sizes with decreasing fish abundances in lakes from northern Europe and Oceania (Jeppesen et al., 2002).

We detected no effect of the presence of annual fish on the egg size of cladocerans. Assuming that smaller eggs will hatch into smaller species or smaller initial life stages of individuals, it is likely that fish will rather focus on larger and more easily spotted invertebrates leaving smaller ones in greater densities (see Jeppesen et al., 2010). Size-oriented dietary preference is common in many planktivorous fish (Zhang et al., 2013). It is assumed that zooplankton species with smaller body size are less attractive or valuable as prey to annual fishes (Keppeler et al., 2015; Waterkeyn et al., 2016), and thus less prone to be preyed upon than larger-bodied species (Zaret, 1980; Walls et al., 1990). In addition, the occurrence of small-sized cladoceran species is reported in lentic environments with different predation pressures by fish (Iglesias et al., 2011), and a similar pattern might have occurred in our temporary ponds. The limited effect of fish predators on small-bodied cladocerans is known, despite concurrent predation pressure increases for the larger zooplankton taxa, such as Daphnia (Santangelo et al., 2010). Nonetheless, in tropical and subtropical regions zooplankton species smaller than Daphnia are more common (Havens et al., 2009). Santangelo et al. (2011), for instance, reports that the small-bodied Moina micrura (up to $1.0 \mathrm{~mm}$ in length) has an effective response to predation by the three-spined stickleback, Gasterosteus aculeatus, such as increase in clutch size and reduction in body length of neonates.

We must highlight the limited sample size of this study and that our results come from laboratory experiments and did not consider natural variation in environmental factors such as light/dark patterns, temperature, salinity (Butorina, 2004; Nielsen et al., 2012; Sipaúba-Tavares et al., 2014; Haridevan et al., 2015; Strachan et al.,
2016), as well as biological interactions among the predatory fish themselves. These variables can also affect zooplankton population dynamics (Brendonck \& De Meester, 2003; Vandekerkhove et al., 2005; Araújo et al., 2013).

\section{CONCLUSION}

Our study detected limited short-term (from the previous hydrologic year) effects of annual fish predators on the assemblages of emerging stages of aquatic invertebrate in temporary ponds from southern Brazil. These results could have been driven by dietary preferences or ontogenetic contingencies of the annual fish, or even interannual variation in fish occurrence among ponds. In fact, evaluations restricted to ponds containing fish have found that higher annual fish population sizes were associated with lower richness and abundance of hatchlings, suggesting that the effects of annual fish on aquatic invertebrates are more related to predator density than their presence. In summary, these results are in accordance with recent reviews indicating that fish have limited effect on the assemblage structure of the zooplankton hatchlings, compared to the known effects of fish on the active stages of zooplankton species.

\section{ACKNOWLEDGEMENTS}

This study was funded by the Brazilian National Research Council (CNPq - grant number 474892/2013-1). Cristina Stenert and Leonardo Maltchik hold CNPq Research Productivity grants. CAPES (Coordination for the Improvement of Higher Education Personnel) currently grants a PhD scholarship to Daiane Vendramin. Mateus Marques Pires is currently a postdoctoral research fellow at Unisinos, funded by $\mathrm{CNPq}$. Martin Reichard received grant from the Czech Science Foundation project (P505/12/G112). We declare that data collection complied with current Brazilian environmental laws (SISBIO 36365-2).

\section{REFERENCES}

ABNT - Brazilian Technical Standards Association. 2006. Guidelines for aquatic ecotoxicology (Chronic Toxicity) test method with Ceri- 
odaphnia spp (Crustacea, Cladocera) (Brazilian Standards - NBR 13373). 2nd ed. Brazilian Technical Standards Association, Rio de Janeiro, pp. 1-20.

ARAÚJO, L. R., P.M. LOPES, J. M. SANTANGELO, A. C. PETRY \& R. L. BOZELLI. 2013. Zooplankton resting egg banks in permanent and temporary tropical aquatic systems. Acta Limnologica Brasiliensia, 25: 235-245. DOI: 10.1590/S2179-975X2013000300004

ARENZON, A., A. C. PERET \& M. B. C. BOHRER. 1999. Reproduction of the annual fish Cynopoecilus maelanotaenia (Regan 1912) based on a temporary water body population in Rio Grande do Sul State, Brazil. Hydrobiologia, 411: 65-70. DOI: 10.1023/A: 1003868711295

ÁVILA, A. C., T. BOELTER, R. M. SANTOS, C. STENERT, N. L. WÜRDIG, O. ROCHA \& L. MALTCHIK. 2015. The effects of different rice cultivation systems and ages on resting stages of wetland invertebrates in southern Brazil. Marine and Freshwater Research, 66: 276-285. DOI: 10.1071/MF14048

BOZELLI, R. L., M. TONSI, F. SANDRINI \& M. MANCA. 2008. A Big Bang or small bangs? Effects of biotic environment on hatching. Journal of Limnology, 67:100-106. DOI: $10.4081 /$ jlimnol.2008.100

BRENDONCK, L. \& L. DE MEESTER. 2003. Egg banks in freshwater zooplankton: evolutionary and ecological archives in the sediment. Hydrobiologia, 491: 65-84. DOI: 10.1023/A:1024454905119

BROCK, M. A., D. L. NIELSEN \& K. CROSSLÉ. 2005. Changes in biotic communities developing from freshwater wetland sediments under experimental salinity and water regimes. Freshwater Biology, 50: 1376-1390.

BROOKS, J. L. \& S. I. DODSON. 1965. Predation, body size, and composition of the plankton. Science, 150: 28-35. DOI: 10.1126/science.150.3692.28

BURNHAM, K. P. \& D. R. ANDERSON. 2002. Model selection and multimodel inference: $a$ practical information-theoretic approach. 2nd ed. Springer. NY. USA.

BUTORINA, L. G. 2004. Conditions of develop- ment and hatching from resting eggs in Polyphemus pediculus (Crustacea: Branchiopodiodes). Hydrobiological Journal, 40: 30-40. DOI: 10.1615/HydrobJ.v40.i1.30

DE MEESTER, L. \& H. DE JAGER. 1993. Hatching of Daphnia sexual eggs. II. The effect of age and a second stimulus. Freshwater Biology, 30: 227-233.

DZIALOWSKI, A. R., J. T. LENNON, W. J. O'BRIEN \& V. H. SMITH. 2003. Predator-induced phenotypic plasticity in the exotic cladoceran Daphnia lumholtzi. Freshwater Biology, 48:1593-1602. DOI: 10.1046/j.13652427.2003.01111.x

ELMOOR-LOUREIRO, M. A. L. 1997. Identification manual of limnic cladocerans from Brazil. Universa. DF. Brazil.

FAHD, K., M. FLORENCIO, C. KELLER \& L. SERRANO. 2007. The effect of the sampling scale on zooplankton community assessment and its implications for the conservation of temporary ponds in South West Spain. Aquatic Conservation, 17: 175-193. DOI: 10.1002/ aqc. 781

GAIKWAD, S. R., K. N. INGLE \& S. R. THORAT. 2008. Study of zooplankton emergence pattern and resting egg diversity of recently dried waterbodies in North Maharashtra Region. Journal of Environmental Biology, 29: 353-356.

GAZULHA, V. 2012. Limnic Zooplankton. Illustrated manual. 1st ed. Technical Books.RJ. Brazil.

GONÇALVES, C. S., U. P. SOUZA \& M. V. VOLCAN. 2011. The opportunistic feeding and reproduction strategies of the annual fish Cynopoecilus melanotaenia (Cyprinodontiformes: Rivulidae) inhabiting ephemeral habitats on Southern Brazil. Neotropical Ichthyology, 9: 191-200. DOI: 10.1590/S167962252011000100019

HAMMILL, E., T. B. ATWOOD, P. CORVALAN, \& D. S. SRIVASTAVA. 2015. Behavioural responses to predation may explain shifts in community structure. Freshwater Biology, 60: 125-135. DOI: 10.1111/ fwb. 12475

HARIDEVAN, G., R. JYOTHIBABU, N. ARUNPANDI, L. JAGADEESAN \& A. 
BIJU. 2015. Influence of salinity on the life table demography of a rare Cladocera Latonopsis australis. Environmental Monitoring and Assessment, 187: 643-658. DOI: 10.1007/ s10661-015-4849-z

HAVENS, K. E., A. C. ELIAM, I. TATICCHI \& R. S. FULTON. 2009. Zooplankton-phytoplankton relationships in shallow subtropical versus temperate lakes Apopka (Florida, USA) and Trasimeno (Umbria, Italy). Hydrobiologia, 628:165-175. DOI: 10.1007/s10750009-9754-4

IGLESIAS, C., N. MAZZEO, G. GOYENOLA, C. FOSALBA, F. T. MELLO, S. GARCÍA \& E. JEPPESEN. 2008. Field and experimental evidence of the effect of Jenynsia multidentata, a small omnivorous-planktivorous fish, on the size distribution of zooplankton in subtropical lakes. Freshwater Biology. DOI: 10.1111/j.1365-2427.2008.02007.x

IGLESIAS, C., N. MAZZEO, M. MEERHOFF, G. LACEROT, J. M. CLEMENTE, F. SCASSO, C. KRUK, G. JEOYENOLA, J. GARCÍA-ALONSO, S. L. AMSINCK, J. C. PAGGI, S. J. PAGGI \& E. JEPPESEN. 2011. High predation is of key importance for dominance of small bodied zooplankton in warm shallow lakes: evidence from lakes, fish exclosures and surface sediments. Hydrobiologia, 667: 133-147. DOI: 10.1007/s10750011-0645-0

IGLESIAS, C., C. BONECKER, L. BRANDÃO, M. C. CRISPIM, E. M. ESKINAZI-SANT'ANNA, M. GERHARD, J. L. PORTINHO, P. MAIA-BARBOSA, E. PANARELLI \& J. M. SANTANGELO. 2016. Current knowledge of South American cladoceran diapause: A brief review. International Review of Hydrobiology, 101: 1-14. DOI: 10.1002/iroh.201501825.

JENKINS, K. M. \& A. J. BOULTON. 2007. Detecting impacts and setting restoration targets in arid-zone Rivers: aquatic micro-invertebrate responses to reduced floodplain inundation. Journal of Applied Ecology, 44: 823-832. DOI: 10.1111/j.1365-2664.2007. 01298.x

JEPPESEN, E., P. LEAVITT, L. DE MEESTER \& J. P. JENSEN. 2001. Functional ecology and palaeolimnology: using cladoceran remains to reconstruct anthropogenic impact. Trends Ecology Evolution, 16:191-198. DOI: 10.1016/S0169-5347(01)02100-0

JEPPESEN, E., J. P. JENSEN, S. AMSINCK, F. LANDKILDEHUS, T. LAURIDSEN \& S. F. MITCHELL. 2002. Reconstructing the historical changes in Daphnia mean size and planktivorous fish abundance in lakes from the size of Daphnia ephippia in the sediment. Journal of Paleolimnology, 27: 133-143. DOI: 10.1023/A:1013561208488

JEPPESEN, E. M., K. MEERHOFF, I. HOLMGREN, F. GONZÁLEZ-BERGONZONI, S. T. MELLO, L. DECLERCK, L. DE MEESTER, M. SØNDERGAARD, T. L. LAURIDSEN, R. BJERRING, J. M. CONDE-PORCUNA, N. MAZZEO, C. IGLESIAS, M. REIZENSTEIN, H. J. MALMQUIST, Z. LIU, D. BALAYLA \& X. LAZZARO. 2010. Impacts of climate warming on lake fish community structure and potential effects on ecosystem function. Hydrobiologia, 646: 73-90. DOI: 10.1007/s10750010-0171-5

KEDEM, H., C. COHEN, I. MESSIKA, M. EINAV, S. PILOSOF \& H. HAWLENA. 2014. Multiple effects of host-species diversity on coexisting host-specific and host-opportunistic microbes. Ecology, 95:1173-1183. DOI: 10.1890/13-0678.1

KEPPELER, F. W., L. E. K. LANÉS, A. S. ROLON, C. STENERT \& L. MALTCHIK. 2013. The diet of Cynopoecilus fulgens Costa, 2002 (Cyprinodontiformes: Rivulidae) in Southern Brazil wetlands. Italian Journal of Zoology, 80: 291-302. DOI: 10.1080/ 11250003.2012.744107

KEPPELER, F. W., L. E. K. LANÉS, A. S. ROLON, C. STENERT, P. LEHMANN, M. REICHARD \& L. MALTCHIK. 2015. The morphology-diet relationship and its role in the coexistence of two species of annual fishes. Ecology Freshwater Fish, 24: 77-90. DOI: $10.1111 /$ eff. 12127

LANÉS, L. E. K., A. C. GONÇALVES \& M. V. VOLCAN. 2013. Austrolebias arachan Loureiro, Azpelicueta and García 2004 (Cyprinodonfiformes: Rivulidae) in Rio Grande do 
Sul, Brazil: occurrence, length-weight relationships and condition factor. Journal of Applied Ichthyology, 29: 252-256. DOI: 10.1111/j.1439-0426.2012.02052.x

LANÉS, L. E. K., A. C. GONÇALVES \& M. V. VOLCAN. 2014. Discovery of endangered annual killifish Austrolebias cheradophilus (Aplocheiloidei: Rivulidae) in Brazil, with comments on habitat, population structure and conservation status. Neotropical Ichthyology, 12: 117-124. DOI: 10.1590/S167962252014000100012

LANÉS, L. E. K., A. S. ROLON, C. STENERT \& L. MALTCHIK. 2015. Effects of an artificial and annual opening of a natural sandbar on the fish community in a coastal lagoon system: a case study in Lagoa do Peixe floodplains, Southern Brazil. Journal of Applied Ichthyology, 31: 321-327. DOI: 10.1111/jai.12687

LANÉS, L. E. K., R. S. GODOY, L. MALTCHIK, M. POLAČIK, R. BLAŽEK \& M. REICHARD. 2016. Seasonal dynamics in community structure, abundance, body size and sex ratio in two species of Neotropical annual fishes. Journal of Fish Biology, 89:2345-2364. DOI: 10.1111/jfb.13122

LANÉS, L. E. K., M. REICHARD, R. G. MOURA, R. S GODOY \& L. MALTCHIK. 2018. Environmental predictors for annual fish assemblages in subtropical grasslands of South America: the role of landscape and habitat characteristics. Environmental Biology of Fishes, 101:963-977. DOI: 10.1007/s10641018-0751-1

LAUFER, G., M. ARIM, M. LOUREIRO, J. M. PIÑEIRO-GUERRA, S. CLAVIJO-BAQUET \& C. FAGÚNDEZ. 2009. Diet of four annual killifishes: an intra and interspecific comparison. Neotropical Ichthyology, 7: 77-86. DOI: 10.1590/S1679-62252009000100010

LEMMA, B., J. BENNDORF \& R. KOSCHEL. 2001. Fish predation pressure on and interactions between cladocerans: Observations using enclosures in three temperate lakes (Germany) and one tropical lake (Ethiopia). Limnologica, 31:209-220. DOI: 10.1016/ S0075-9511(01)80023-2

LOPRETTO, E. C. \& G. TELL. 1995. Ecosistemas de aguas continentales: metodologías para su estudio. Ediciones Sur. La Plata. Argentina.

MAIA-BARBOSA, P. M., E. M. ESKINAZI-SANT'ANNA, C. F. VALADARES \& G. C. D. PESSOA. 2003. The resting eggs of zooplankton from a tropical, eutrophic reservoir (Pampulha Reservoir, south-east Brazil). Lakes and Reservoirs: research and Management, 8: 269-275. DOI: 10.1111/j.1440-1770. 2003.00229.x

MALTCHIK, L., E. S. COSTA, C. G. BECKER \& A. E. OLIVEIRA. 2003. Inventory of wetlands of Rio Grande do Sul (Brazil). Pesquisa Botânica 53: 89-100.

MAZZEO, N., C. IGLESIAS, F. T. MELLO, A. BORTHAGARAY, C. FOSALBA, R. BALLABIO, D. LARREA, J. VILCHES, S. GARCÍA, J. P. PACHECO \& E. JEPPESEN. 2010. Trophic cascade effects of Hoplias malabaricus (Characiformes, Erythrinidae) in subtropical lakes food webs: a mesocosm approach. Hydrobiologia, 644:325-335. DOI: 10.1007/s10750-010-0197-8

MEDEIROS, E. S. F. \& A. H. ARTHINGTON. 2008. The importance of zooplankton in the diets of three native fish species in floodplain waterholes of a dryland river, the Macintyre River, Australia. Hydrobiologia, 614: 19-31. DOI: $10.1007 / \mathrm{s} 10750-008-9533-7$

MEERHOFF, M., J. M. CLEMENTE, F. T. MELLO, C. IGLESIAS, A. PEDERSEN \& E. JEPPESEN. 2007. Can warm climate-related structure of littoral predator assemblies weaken the clear water state in shallow lakes? Global Change Biology, 13:1888-1897. DOI: 10.1111/j.1365-2486.2007.01408.x

MERGEAY, J., D. VERSCHUREN, L. V. KERCKHOVEN \& L. DE MEESTER. 2004. Two hundred years of a diverse Daphnia community in Lake Naivasha (Kenya): effects of natural and human-induced environmental changes. Freshwater Biology, 49:998-1013. DOI: $10.1111 / \mathrm{j} .1365-2427.2004 .01244 . x$

MERGEAY, J., S. DECLERCK, D. VERSCHUREN \& L. DE MEESTER. 2006. Daphnia community analysis in shallow Kenyan lakes and ponds using dormant eggs in surface sediments. Freshwater Biology, 51:399-411. DOI: $10.1111 /$ j.1365-2427.2005.01494.x 
MIKULSKI, A. \& J. PIJANOWSKA. 2009. Maternal experience can enhance production of resting eggs in Daphnia exposed to the risk of fish predation. Fundamental and Applied Limnology, 174:301-305. DOI: 10.1127/18639135/2009/0174-0301

NIELSEN, D. L., F.J. SMITH, T. J. HILLMAN \& R. J. SHIEL. 2000. Impact of water regime and fish predation on zooplankton resting egg production and emergence. Journal of Plankton Research, 22: 433-446. DOI: 10.1093/ plankt/22.3.433

NIELSEN, D. L., M. A. BROCK, K. CROSSLÉ, K. HARRIS, M. HEALEY \& I. JAROSINSKI. 2003. The effects of salinity on aquatic plant germination and zooplankton hatching from two wetland sediments. Freshwater Biology, 48: 2214-2223.

NIELSEN, D. L., D. SMITH \& R. PETRIE. 2012. Resting egg banks can facilitate recovery of zooplankton communities after extended exposure to saline conditions. Freshwater Biology, 57: 1306-1314. DOI: 10.1111/j.13652427.2012.02782.x

NIELSEN, D. L., K. PODNAR, R. J. WATTS. \& A. L. WILSON. 2013. Empirical evidence linking increased hydrologic stability with decreased biotic diversity within wetlands. Hydrobiologia, 708: 81-96.

NILSSON, P. A. 2001. Predator behaviour and prey density: evaluating density-dependent intraspecific interactions on predator functional responses. Journal of Animal Ecology 70: 14-19. https://www.jstor.org/stable/2693475.

ORTIZ, E. \& M. ARIM. 2016. Hypotheses and trends on how body size affects trophic interactions in a guild of South American killifishes. Austral Ecology, 41: 976-982. DOI: 10.1111/ aec. 12389

PEEL, M. C., B. L. FINLAYSON \& T. A. MCMAHON. 2007. Updated world map of the Köppen-Geiger climate classification. Hydrology and Earth System Sciences, 11: 1633-1644. DOI: 10.5194/hess-11-1633-2007 PIJANOWSKA, J. \& G. STOLPE. 1996. Summer diapause in Daphnia as a reaction to the presence of fish. Journal of Plankton Research, 18:1407-1412. DOI: 10.1093/plankt/18.8.1407 R DEVELOPMENT CORE TEAM. 2009. $R: A$ language and Environment for Statistical Computing. R Foundation for Statistical Computing. Vienna. Austria.

RAMBO, B. 2000. A Fisionomia do Rio Grande do Sul: Ensaio de Monografia Natural. Universidade do Vale do Rio dos Sinos (UNISINOS). São Leopoldo. Brazil.

REICHARD, M. 2015. The evolutionary ecology of African annual fishes. In: Berois N, García G, de Sá R (eds) Annual fishes: life history strategy, diversity, and evolution. Boca Raton. Boca Raton. USA.

ROLON, A. S., O. ROCHA \& L. MALTCHIK. 2011. Does pine occurrence influence the macrophyte assemblage in Southern Brazil ponds? Hydrobiologia, 675: 157-165. DOI: 10.1007/s10750-011-0813-2

SAKWIŃSKA, O. 2002. Response to fish kairomone in Daphnia galeata life history traits relies on shift to earlier instar at maturation. Oecologia, 131: 409-417. DOI: 10.1007/ s00442-002-0901-0

SANTANGELO, J. M. 2009. Produção, eclosão e implicações ecológicas e evolutivas dos estágios dormentes do zooplâncton. Limnotemas. Sociedade Brasileira de Limnologia, Porto Alegre.

SANTANGELO, J. M., R. L. BOZELLI, F. A. ESTEVES \& R. TOLLRIAN. 2010. Predation cues do not affect the induction and termination of diapause in small-bodied cladocerans. Freshwater Biology, 55: 1577-1586. DOI: $10.1111 / \mathrm{j} .1365-2427.2009 .02389$

SANTANGELO, J. M., F. A. ESTEVES, R. TOLLRIAN \& R. L. BOZELLI. 2011. A small-bodied cladoceran (Moina micrura) reacts more strongly to vertebrate than invertebrate predators: a transgenerational life-table approach. Journal of Plankton Research, 33: 1767-1772. DOI: 10.1093/plankt/fbr063.

SILVA, M. J., B. R. S. FIGUEIREDO, R. T. C. RAMOS \& E. S. F. MEDEIROS. 2010. Food resources used by three species of fish in the semi-arid region of Brazil. Neotropical Ichthyology, 8: 825-833. DOI: 10.1590/S167962252010005000010

SIPAÚBA-TAVARES, L. H., B. S. TRUZZI \& F. A. BERCHIELLI-MORAIS. 2014. Growth and development time of subtropical 
Cladocera Diaphanosoma birgei Korinek, 1981 fed with different microalgal diets. Brazilian Journal of Biology, 74: 464-471. DOI: 10.1590/1519-6984.12012

SIZIBA, N., M. J. CHIMBARI, H. MASUNDIRE, K. MOSEPELE \& L. RAMBERG. 2013. Variation in assemblages of small fishes and microcrustaceans after inundation of rarely flooded wetlands of the lower Okavango Delta, Botswana. Environmental Management, 52: 1386-1399. DOI: 10.1007/s00267013-0183-9

SKAUG H, D. FOURNIER. B. BOLKER, A. MAGNUSSON \& A. NIELSEN. 2016. Generalized Linear Mixed Models using 'AD Model Builder'. R package version 0.8.3.3.

SLATKIN, M. 1974. Hedging one's evolutionary bets. Nature, 250: 704-705.

ŚLUSARCZYK, M. 1995. Predator induced diapause in Daphnia. Ecology, 76:1008-1013. https://www.jstor.org/stable/1939364.

ŚLUSARCZYK, M. 1999. Predator-induced diapause in Daphnia magna may require two chemical cues. Oecologia, 119: 159-165. DOI: $10.1007 / \mathrm{s} 004420050772$

ŚLUSARCZYK, M. 2001. Food threshold for diapause in Daphnia under the threat of fish predation. Ecology, 82: 1089-1096. DOI: 10.1890/0012-9658(2001)082[1089:FTFDID] 2.0.CO;2

STENERT, C., R. C. BACCA, A. C. ÁVILA, L. MALTCHIK \& O. ROCHA. 2010. Do hydrologic regimes used in rice fields compromise the viability of resting stages of aquatic invertebrates? Wetlands, 30: 989-996. DOI: 10.1007/ s13157-010-0083-1

STENERT, C., R. C. BACCA, A. B. MORAES, A. C. ÁVILA \& L. MALTCHIK. 2012. Negative effects of exotic pine invasion on macroinvertebrate communities in southern Brazil coastal ponds. Marine Freshwater Research, 63: 283-292. DOI: 10.1071/MF11169

STRACHAN, S., R. E. T. CHESTER \& B. J. RODSON. 2016. Habitat alters the effect of false starts on seasonal-wetland invertebrates. Freshwater Biology, 61: 680-692. DOI: 10.1111/fwb.12738

TOLLRIAN, R., S. DUGGEN, L. WEISS, C. LAFORSCH \& M. KOPP. 2015. Density-de- pendent adjustment of inducible defenses. Scientific Reports, 5: 12736. DOI: 10.1038/ srep 12736

VANDEKERKHOVE, J., B. NIESSEN, S. DECLERCK, E. JEPPESEN, J. M. CONDEPORCUNA, L. BRENDONCK \& L. DE MEESTER. 2004a. Hatching rate and success of isolated versus non-isolated zooplankton eggs. Hydrobiologia, 526: 235-241. DOI: 10.1023/B:HYDR.0000041598.68424.fc

VANDEKERKHOVE, J., S. DECLERCK, M. VANHOVE, L. BRENDONCK, E. JEPPESEN, J. M. CONDE-PORCUNA \& L. DE MEESTER. 2004b. Use of ephippial morphology to assess richness of anomopods: potentials and pitfalls. Journal of Limnology, 63: 75-84. DOI: 10.4081/jlimnol.2004.s1.75

VANDEKERKHOVE, J., S. DECLERCK, E. JEPPESEN, J. M. CONDE-PORCUNA, L. BRENDONCK \& L. DE MEESTER. 2005. Dormant propagule banks integrate spatio-temporal heterogeneity in cladoceran communities. Oecologia, 142: 109-116. DOI: 10.1007/s00442-004-1711-3

WALLS, M., I. KORTELAINEN \& J. SARVALA. 1990. Prey responses to fish predation in freshwater communities. Annales Zoologici Fennici, 27: 183-199. https://www.jstor.org/ stable/23736038.

WALSENG, B., T. ANDERSEN \& D. O. HESSEN. 2015. Higher zooplankton species richness associated with an invertebrate top predator. Freshwater Biology, 60: 903-910. DOI: $10.1111 /$ fwb. 12543

WATERKEYN, A., P. GRILLAS \& L. BRENDONCK. 2016. Experimental test of the ecosystem impacts of the keystone predator Triops cancriformis (Branchiopoda: Notostraca) in temporary ponds. Freshwater Biology, 61: 1392-1404. DOI: 10.1111/fwb.12779

WILLIAMS, M. 1993. Wetlands: a threatened landscape. Oxford Blackwell Publishers. UK. WILLIAMS, D. D. 2006. The biology of temporary waters. Oxford University Press. Canada.

ZARET, T. M. 1980. Predation and Freshwater Communities. Yale University Press. New Haven. USA.

ZHANG, J., P. XIE, M. TAO, L. GUO, J. CHEN, L. LI, X. Z. ZHANG \& L. ZHANG. 2013. 
The impact of fish predation and cyanobacteria on zooplankton size structure in 96 subtropical lakes. Plos One, 8(10): e76378.

DOI: 10.1371/journal.pone.0076378

Con el patrocinio de:

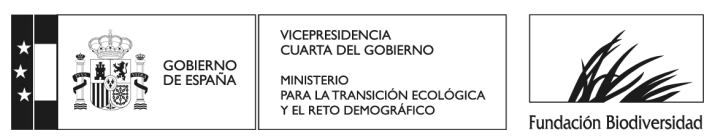

